University of Wollongong

Research Online

Faculty of Engineering and Information

Faculty of Engineering and Information

Sciences - Papers: Part A

Sciences

$1-1-2014$

A new quaternary phase observed in a laser treated $\mathrm{Zn}-\mathrm{Al}-\mathrm{Mg}$-Si coating

Z Chen

University of Wollongong, zchen@uow.edu.au

C.-T Peng

University of Wollongong, ctp224@uowmail.edu.au

Q Liu

BlueScope Steel Limited, qliu@uow.edu.au

R Smith

BlueScope Steel Limited

D Nolan

BlueScope Steel Limited

Follow this and additional works at: https://ro.uow.edu.au/eispapers

Part of the Engineering Commons, and the Science and Technology Studies Commons

Research Online is the open access institutional repository for the University of Wollongong. For further information contact the UOW Library: research-pubs@uow.edu.au 


\title{
A new quaternary phase observed in a laser treated Zn-Al-Mg-Si coating
}

\author{
Abstract \\ The microstructure of laser resurfaced $\mathrm{Zn}-55 \mathrm{Al}-2 \mathrm{Mg}-1.5 \mathrm{Si}$ coating produced on a hot-dip simulator was \\ characterised by transmission electron microscopy. A new quaternary phase was observed and its crystal \\ structure was determined by electron diffraction. \\ Keywords \\ si, mg, al, coating, zn, quaternary, treated, laser, observed, phase \\ Disciplines \\ Engineering I Science and Technology Studies \\ Publication Details \\ Chen, Z., Peng, C., Liu, Q., Smith, R. \& Nolan, D. (2014). A new quaternary phase observed in a laser treated \\ Zn-Al-Mg-Si coating. Journal of Alloys and Compounds, 589 226-229.
}

This journal article is available at Research Online: https://ro.uow.edu.au/eispapers/1834 


\title{
A new quaternary phase observed in a laser treated Zn-Al-Mg-Si coating Z. Chen ${ }^{\mathrm{a}, *}$, C.-T. Peng ${ }^{\mathrm{a}}$, Q. Liu ${ }^{\mathrm{b}}$, R. Smith ${ }^{\mathrm{b}}$ and D. Nolan ${ }^{\mathrm{b}}$
}

${ }^{a}$ School of Mechanical, Materials and Mechatronic Engineering, Faculty of Engineering and Information Sciences, University of Wollongong, Wollongong, NSW 2522, Australia ${ }^{\mathrm{b}}$ Bluescope Steel Research, Bluescope Steel Limited, Locked Bag 8825, Wollongong DC NSW 2500, Australia

*Corresponding author. Tel.: +61 4221 4932. E-mail address: zchen@ uowmail.edu.au (Z. Chen)

\begin{abstract}
The microstructure of laser resurfaced $\mathrm{Zn}-55 \mathrm{Al}-2 \mathrm{Mg}-1.5 \mathrm{Si}$ coating produced on a hot-dip simulator was characterised by transmission electron microscopy. A new quaternary phase was observed and its crystal structure was determined by electron diffraction.
\end{abstract}

Keywords: GALVALUME ${ }^{\circledR}$ steel coating; Coating materials; Laser treatment; Crystal structure; Zn-Al-Mg-Si system; Quaternary phase

\section{Introduction}

The GALVALUME ${ }^{\circledR}$ steel coating system (nominally Zn-55Al-1.5Si in wt.\%), developed by Bethlehem Steel in the 1960s, exhibits a greater corrosion resistance than the conventional galvanised coating [1], but challenges remain in certain applications [2]. There is a need to develop a new coating which can demonstrate even better corrosion resistance. Recently, a second generation of GALVALUME ${ }^{\circledR}$ and ZINCALUME ${ }^{\circledR}$ steel coating with the composition of Zn-55Al-2Mg-1.5Si (in wt.\%) was developed and patented by Bluescope Steel Limited. It is claimed that this coating has even better corrosion resistance than the original coating [3]. The addition of $2 \% \mathrm{Mg}$ results in the formation of $\mathrm{Mg}_{2} \mathrm{Si}$ and $\mathrm{MgZn}_{2}$ phases predominantly in the interdendritic regions of the coating and the enhanced corrosion resistance depends on the specific phases present in the coating and their distribution. The enhanced performance of the $\mathrm{Zn}-55 \mathrm{Al}-2 \mathrm{Mg}-1.5 \mathrm{Si}$ coating is achieved by activating the $\alpha-\mathrm{Al}$ dendritic phase and blocking the corrosion paths along the interdendritic channels [4]. Therefore, the amount and distribution of these $\mathrm{Mg}$ containing phases are important to the corrosion performance of the final coated product. Laser surface treatment provides a process to significantly refine the coating structure via extremely high cooling rates during solidification, improve the distribution of phase components and corrosion performance [5]. In this paper we report that a new quaternary phase was observed in a laser resurfaced Zn55Al-2Mg-1.5Si coating and its crystal structure was characterised by TEM.

\section{Experimental}

In this investigation which is a part of a much larger research program on microstructure and phase equilibria of laser treated $\mathrm{Zn}-\mathrm{Al}-\mathrm{Mg}$-Si coatings, a $\mathrm{Zn}-55 \mathrm{Al}-2 \mathrm{Mg}-1.5 \mathrm{Si}$ coating (wt.\%) was produced on a hot-dip process simulator (HDPS) and then resurfaced with a diode laser operating at $5.5 \mathrm{~kW}$. The microstructure of the HDPS Zn-55Al-2Mg-1.5Si coating was studied on a JEOL JSM-6940 SEM at 15kVand the microstructure of the laser resurfaced coating were characterised in a JEOL 2011FX TEM at 200kV. TEM samples of 100nm thick were prepared by using a xT Nova NanoLab 200 Dualbeam focused ion beam miller at $30 \mathrm{kV}$. An aging treatment of the laser treated coatings was carried out in air at $150^{\circ} \mathrm{C}$ for $24 \mathrm{hrs}$. The microstructure of the aged treated sample was also studied by TEM. 


\section{Results and discussion}

Figure 1a shows a backscattered electron image of a cross section of the HDPS Zn-55Al2Mg-1.5Si coating and Figures $1 \mathrm{~b}$-e show the X-ray maps of $\mathrm{Al} \mathrm{K}, \mathrm{Mg} \mathrm{K}, \mathrm{Zn} \mathrm{K}$ and Si K of the same area. Clearly $\mathrm{Zn}, \mathrm{Si}$ and $\mathrm{Mg}$ are segregated in the interdendritic areas and $\mathrm{Si}$ can be present either as pure $\mathrm{Si}$ or as $\mathrm{Mg}_{2} \mathrm{Si}$ (1c and 1e). The microstructure of the interdendritic area of the laser treated $\mathrm{Zn}-55 \mathrm{Al}-2 \mathrm{Mg}-1.5 \mathrm{Si}$ coating is too fine to be resolved in SEM and thus was studied mainly in TEM. Figure 2 shows the TEM microstructure of the overlay of the laser treated $\mathrm{Zn}-55 \mathrm{Al}-2 \mathrm{Mg}-1.5 \mathrm{Si}$ coating. It consists of dendritic $\alpha$-Al matrix, large angular particles and eutectic features in the interdendritic areas. The nodular structures in the interdendritic regions were artefacts of the TEM sample preparation process. The cross section of the $\alpha$ dendrite is about $1 \mu \mathrm{m}$ which is significantly smaller than that of the untreated $\alpha$ dendrite (Figure 1a). TEM/EDS microanalysis was performed on these dendrites, the coarse angular particles and the eutectic $\mathrm{Al}$ and $\mathrm{Zn}$ plates in the interdendritic areas, and the results are given in Table 1.The beam size was about 50nm which is considerable smaller than the particle size so the matrix effect on the results should be negligible. The $\alpha$ dendrite has the average composition of $42 \mathrm{Zn}-55 \mathrm{Al}-1 \mathrm{Mg}-1 \mathrm{Si}$ (wt.\%) which is close to the coating composition due to the extremely fast cooling rate, and the coarse angular particles $(0.4-1 \mu \mathrm{m})$ have the average composition of $51 \mathrm{Zn}-11 \mathrm{Al}-18 \mathrm{Mg}-20 \mathrm{Si}$ (wt.\%). The eutectic $\mathrm{Al}$ and $\mathrm{Zn}$ plates have the composition of $18 \mathrm{Zn}-71 \mathrm{Al}-4 \mathrm{Mg}-5 \mathrm{Si}$ (wt.\%) and 80Zn-17Al-2Mg-1Si (wt.\%), respectively. The eutectic $\mathrm{Al}$ plates contained more $\mathrm{Mg}$ and $\mathrm{Si}$ than expected.

The crystal structure of the coarse interdendritic particles (new phase) was investigated systematically by electron diffraction and a portion of the Kikuchi map was established, as shown in Figure 3. The two major zones axes [llll $\left.0 \begin{array}{ll}0 & 1\end{array}\right]$ and $\left[\begin{array}{lll}1 & 1 & 0\end{array}\right]$ of the phase are given in Figures $4 \mathrm{a}$ and $4 \mathrm{~b}$, respectively. The lattice parameters $\mathrm{a}$ and $\mathrm{b}$ were obtained from the [ $\left[\begin{array}{lll}0 & 0 & 1\end{array}\right]$ and $\mathrm{c}$ was obtained from the $\left[\begin{array}{lll}1 & 1 & 0\end{array}\right]$, giving $a=0.790 \mathrm{~nm}, b=0.695 \mathrm{~nm}$ and $\mathrm{c}=0.414 \mathrm{~nm}$. Clearly the phase has a simple orthorhombic Bravais lattice. The obtained lattice parameters were then used to calculate the angles between the zone axes shown in Figure 3. The calculated angles are well matched with those experimentally measured; therefore the crystal structure of this new phase was confirmed to be an orthorhombic.

The relative coarse size of the orthorhombic phase suggests that the phase was formed at temperatures higher than that of the eutectic reaction of $\mathrm{L} \rightarrow \mathrm{Zn}+\mathrm{Al}$. It is likely that the solidification of the laser resurfaced coating started with the $\alpha-\mathrm{Al}$ dendrite, followed by the formation of the quaternary phase and lastly the eutectic reaction. The hot-dip simulated coating without laser treatment was also studied and pure $\mathrm{Si}$ and $\mathrm{Mg}_{2} \mathrm{Si}$ were observed in the interdendritic areas. It is proposed that upon the laser heating the $\mathrm{Si}$ and $\mathrm{Mg}_{2} \mathrm{Si}$ were melted rapidly, without extended diffusion due to the nature of the rapid heating in the laser treatment. The new orthorhombic phase was formed in the regions with highly concentrated $\mathrm{Mg}$ and $\mathrm{Si}$, and grew rapidly. The formation of this phase led to the composition of the remaining liquid approaching the eutectic composition of binary Al-Zn, and finally the fine eutectic $\mathrm{Al}$ and $\mathrm{Zn}$ were formed. The relative fine plates of the $\mathrm{Al}$ and $\mathrm{Zn}$ indicate that the eutectic reaction occurred at relative low temperatures.

In view of the fact that the new orthorhombic phase was not observed in the untreated coating, it is possible that the phase is a metastable phase introduced by the laser treatment process because of the superfast cooling rate. A subsequent aging treatment of the laser treated sample was conducted at $150^{\circ} \mathrm{C}$ for $24 \mathrm{hrs}$ in air to test stability. TEM microstructure of the 
aged coating is shown in Figure 5. It can be seen that the orthorhombic phase is surrounded by $\mathrm{Zn}$-rich particles which were precipitated during the aging treatment. In addition, $\mathrm{Mg}_{2} \mathrm{Si}$ particles were also observed in the interdendritic area. The compositions of the $\alpha$ matrix, orthorhombic phase, $\mathrm{Mg}_{2} \mathrm{Si}$ and $\mathrm{Zn}$-rich particles are given in table 2. Clearly the composition of the orthorhombic phase was not altered by the aging treatment. The composition of the $\alpha$ matrix, as expected, has changed a lot after the aging treatment due to mainly the precipitation of $\mathrm{Zn}$ particles. The absence of $\mathrm{Mg}_{2} \mathrm{Si}$ particles in the laser treated samples and significantly finer size of the $\mathrm{Mg}_{2} \mathrm{Si}$ particles in the aged sample may suggest that the $\mathrm{Mg}_{2} \mathrm{Si}$ was formed during the aging treatment at $150^{\circ} \mathrm{C}$. The observation of the new orthorhombic phase in the aging treated coatings suggests that it may not be a metastable phase induced by the extremely fast cooling rate of the laser resurfacing treatment. This is further supported by the observation of the quaternary phase in other laser treated coatings namely $55 \mathrm{Al}-\mathrm{Zn}-3 \mathrm{Mg}-1.5 \mathrm{Si}$ and $55 \mathrm{Al}-\mathrm{Zn}-5 \mathrm{Mg}-4 \mathrm{Si}$ where the quaternary phase was observed in the naturally aged (6 month at room temperature) and aged samples (the same aging treatment) but not observed in the fresh laser treated samples.

This new phase may be a genuine quaternary phase because it contains four different elements and three of them are in similar amount and the fourth one is only slightly less than the rest (in at.\%) and its composition or crystal structure does not match any known phases reported in Al-Zn-Mg [6] or Al-Zn-Si [7] or Al-Zn-Mg-Si [8,9] or Mg-Zn-Si [10], or Al-Mg$\mathrm{Si}$ [11] systems. The new phase may be important to the corrosion properties of rapidly solidified '55\% Al'- $\mathrm{Zn}-\mathrm{Mg}-\mathrm{Si}$ coatings. Since it replaces the interdendritic $\mathrm{Mg}_{2} \mathrm{Si}$ and $\mathrm{MgZn}_{2}$ observed in the interdendritc regions of untreated $\mathrm{Zn}-55 \mathrm{Al}-2 \mathrm{Mg}-1.5 \mathrm{Si}$ coating the corrosion behaviour of the laser treated $\mathrm{Zn}-55 \mathrm{Al}-2 \mathrm{Mg}-1.5 \mathrm{Si}$ coating would expected to be significantly different from that of the untreated $\mathrm{Zn}-55 \mathrm{Al}-2 \mathrm{Mg}-1.5 \mathrm{Si}$ coating. Clearly the laser resurfacing does not only refine the microstructure of the coating but also change the phases in the interdendritic areas.

\section{Conclusions}

A new quaternary phase was observed in the interdendritic area of a laser treated $\mathrm{Zn}-\mathrm{Al}-\mathrm{Mg}$ Si coating and its crystal structure was determined by electron diffraction to be simple orthorhombic with the lattice parameters of $a=0.790 \mathrm{~nm}, b=0.695 \mathrm{~nm}$ and $\mathrm{c}=0.414 \mathrm{~nm}$.

\section{Acknowledgment}

The Authors would like to thank Bluescope Steel Limited for the financial support and for allowing the publication of this work.

\section{References}

[1] H. E. Townsend, Continuous Hot Dip Coatings, ASM Handbook, Vol. 5 (1994), 339-348.

[2] Q. Liu, 2008 China Forum on Development of Continuous Galvanized Steel Sheet, Beijing, China, Oct (2008).

[3] Bluescope Steel Ltd, (2009), International Patent Application, WO2009111842A1.

[4] Bluescope Steel Ltd, (2010), International Patent Application, WO2010102343A1.

[5] Bluescope Steel Ltd, (2007), International Patent Application, WO2007134400A1.

[6] P. Liang, T. Tarfa, J.A. Robinson, S. Wagner, P. Ochin, M.G. Harmelin, H.J. Seifert, H.L. Lukas, F. Aldinger, Thermochimica Acta, 314 (1998) 87-110.

[7] V Raghavan, J phase Equilibria and Diffusion, Vol. 28, No 2 (2007) 197. 
[8] Q. Li, Y.-Z. Zhao, Q. Luo, S.-L. Chen, J.-Y. Zhang, K.-C. Chou, Journal of Alloys and Compounds, 501 (2010) 282-290.

[9] V Raghavan, J phase Equilibria and Diffusion, Vol. 32, No 1 (2011) 72-74.

[10]S. De Negri, M. Skrobańska, S. Delfino, A. Saccone, Intermetallics, 18 (2010) 17221728.

[11]H Feufel, T Godecke, H L Lukas and F Sommer, Journal of Alloys and Compounds, 247 (1997) 31-42.

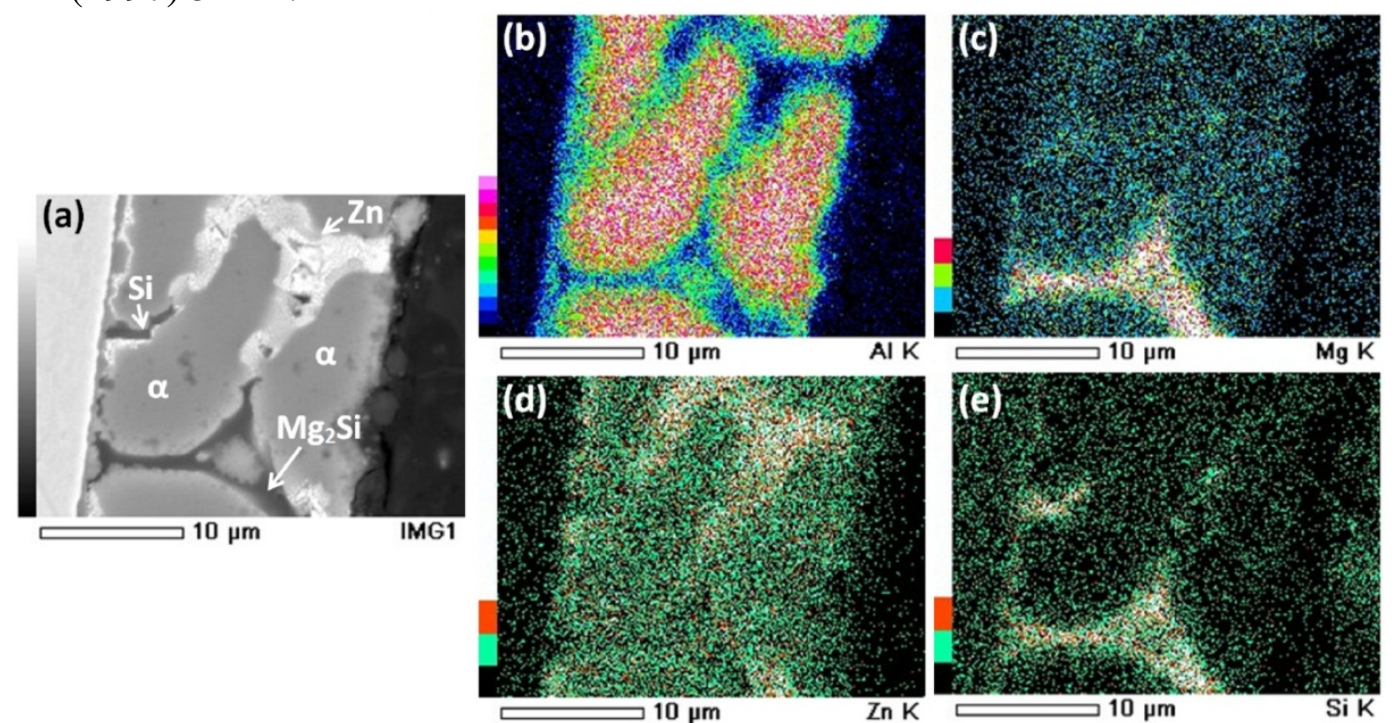

Figure 1. X-ray mapping of the Zn-55Al-2Mg-1.5Si coating.
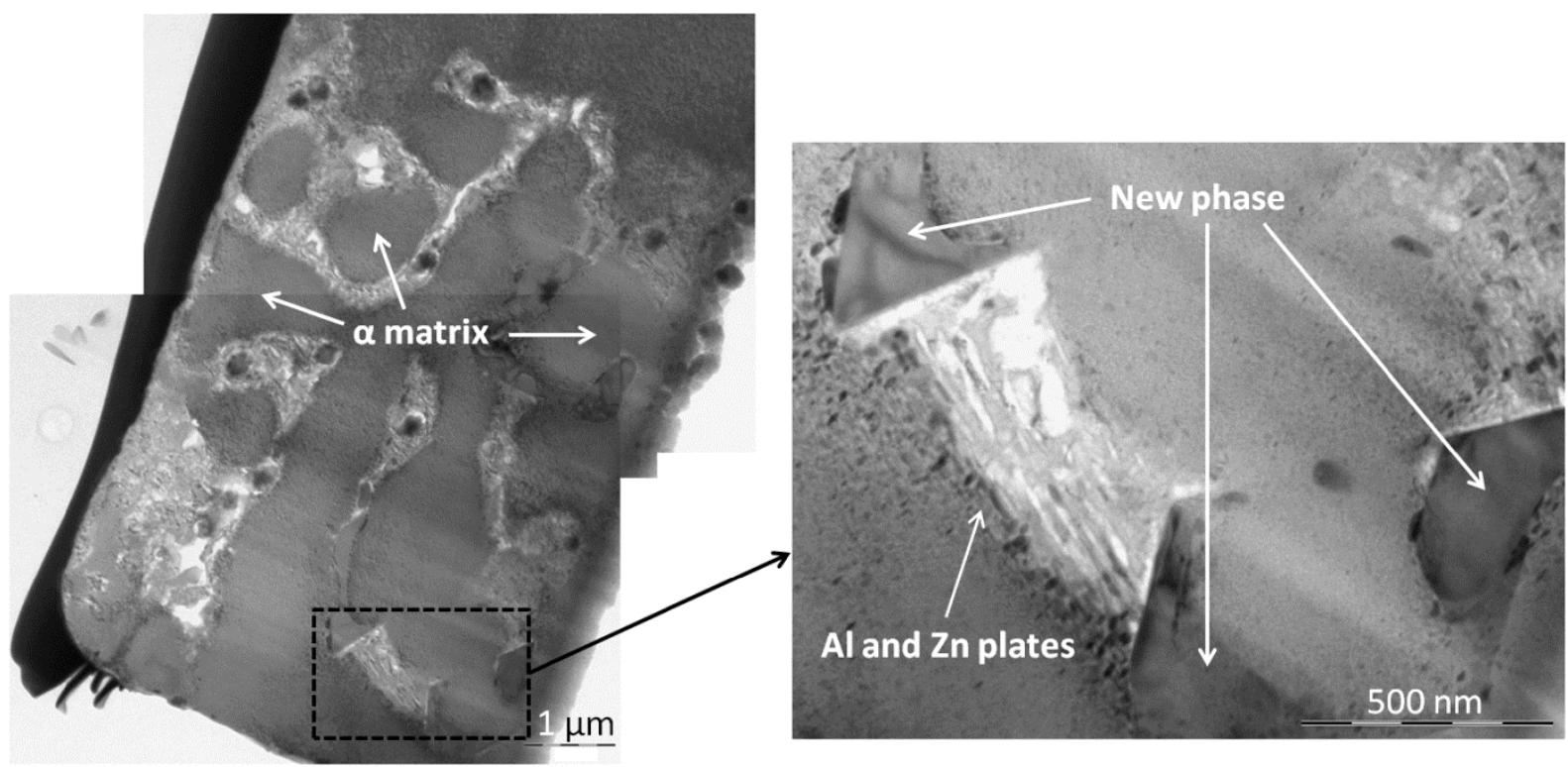

Figure 2. Overlay microstructure of laser treated $\mathrm{Zn}-55 \mathrm{Al}-2 \mathrm{Mg}-1.5 \mathrm{Si}$ coating. 


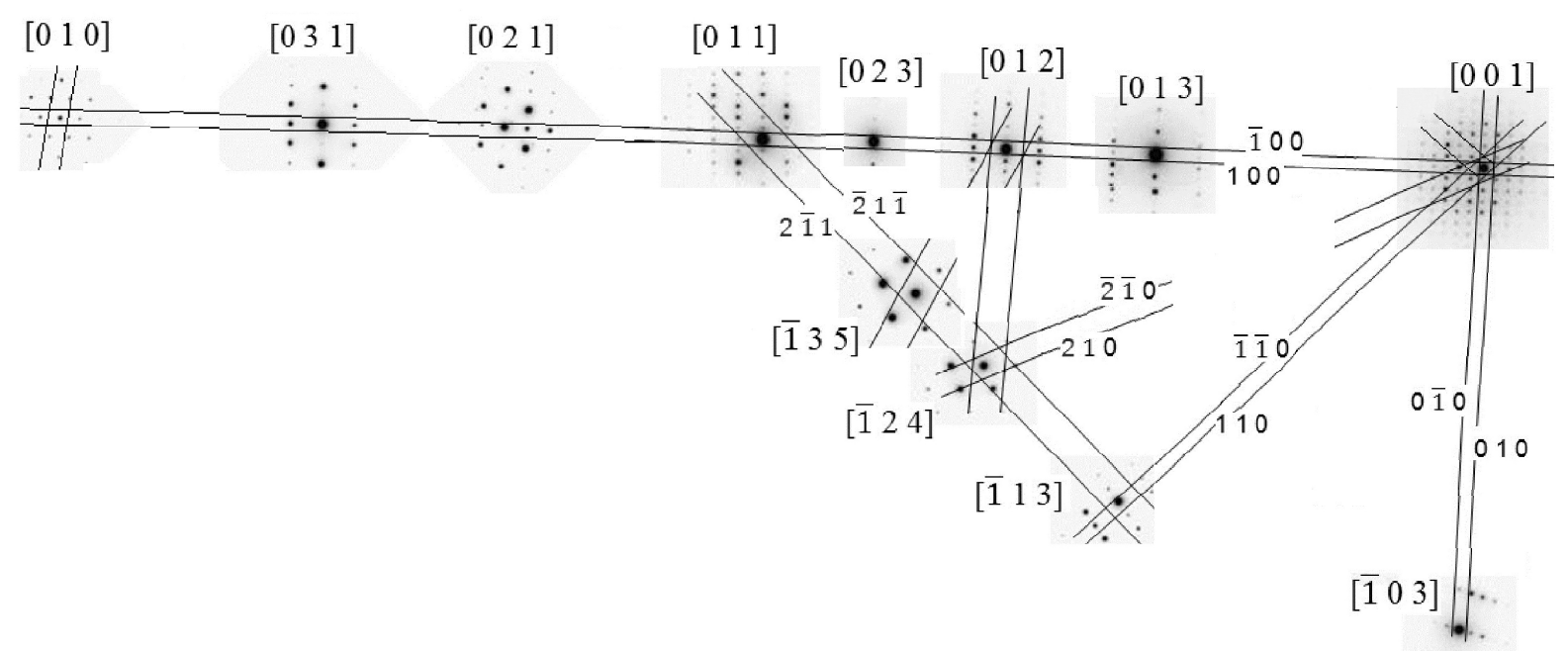

Figure 3. Experimental Kikuchi map of the new orthorhombic phase.

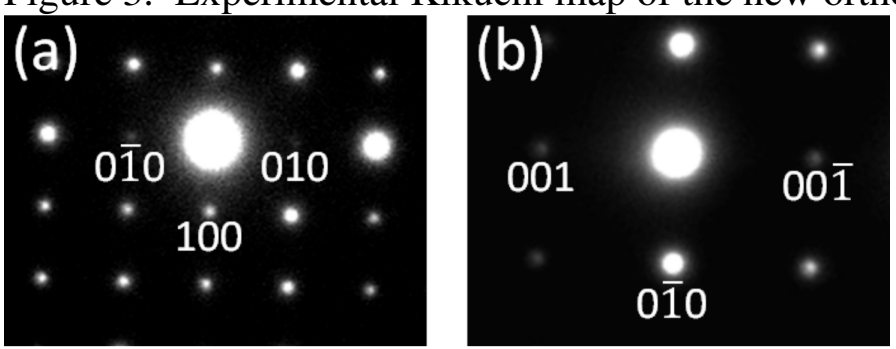

Figure 4. Electron diffraction patterns of (a) [ $\left[\begin{array}{lll}0 & 0 & 1\end{array}\right]$ and (b) [ $\left[\begin{array}{lll}1 & 1 & 0\end{array}\right]$ of the new orthorhombic phase.

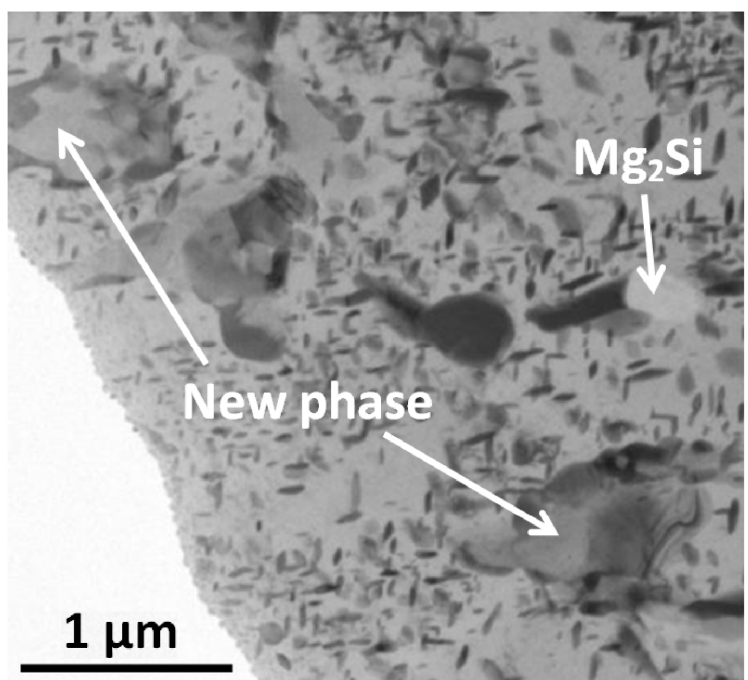

Figure 5. Overlay microstructure of aged $\mathrm{Zn}-55 \mathrm{Al}-2 \mathrm{Mg}-1.5 \mathrm{Si}$ coating. 